Reprod. Nutr. Dévelop., 1984, 24 (5A), 597-608.

\title{
Sperm transport in the cow : peri-ovulatory redistribution of viable cells within the oviduct
}

\author{
R.H.F. HUNTER $\left({ }^{1}\right)$, I. WILMUT $\left({ }^{*}\right)$
}

School of Agriculture, University of Edinburgh

West Mains Road Edinburgh EH9 3JG, UK

(*) Animal Breeding Research Organisation, Dryden Field Laboratory

Roslin, Midlothian EH25 9PS, UK

\begin{abstract}
Summary. Using a surgical approach involving double ligatures and transection, together with subsequent recovery of the eggs, heifers mated at the onset of oestrus have been examined for progression of spermatozoa within the oviducts relative to the time of ovulation; the latter occurred 28-31 hours after the onset of oestrus. Evidence was obtained that spermatozoa competent to penetrate the egg(s) do not pass directly to the site of fertilisation at the isthmic-ampullary junction but instead are largely sequestered before ovulation in the caudal region of the isthmus, possibly for $18-20$ hours or more. Thus, 3 of 14 eggs $(21 \%)$ were fertilised when the oviduct was transected in pre-ovulatory animals $2.0 \mathrm{~cm}$ proximal to the utero-tubal junction 16 or more hours after mating compared with 7 of 8 eggs ( $88 \%$ ) with a similar post-ovulatory transection 28-36 hours after mating $(P<0.01)$. A redistribution of spermatozoa appears to be associated with imminent release of the egg. The distal portion of the oviduct is therefore seen as the functional sperm reservoir - that is the immediate source of viable spermatozoa at the time of ovulation. Parallels are drawn with storage of relatively quiescent sperm cells in the distal portion of the epididymal duct, and procedures of insemination are examined in the light of this storage rôle of the isthmus and the reported incidence of fertilisation in cattle.
\end{abstract}

\section{Introduction.}

Traditional views on the transport and storage of spermatozoa in the genital tract of cows are being challenged by the results of recent studies. Although the timing of transport to the upper region of the oviducts of mated or inseminated animals has been widely cited as requiring five minutes or less, based on the original experiments of VanDemark and Moeller (1951) and VanDemark and Hays (1954), the existence of such rapid transport has been questioned by Dauzier (1958), Thibault (1973) and Thibault, Gérard and Heyman (1973). Moreover, in the stricter context of the events of fertilisation, the time required after mating for a population of competent spermatozoa to have entered the oviducts is measured

(1) All correspondence to RHFH at above address. 
in hours rather than minutes. As judged by their ability to penetrate and activate the newly-ovulated egg, sufficient spermatozoa are not established in the oviducts until 8-12 hours or more have elapsed after mating early in oestrus (Hunter and Wilmut, 1983 ; Wilmut and Hunter, 1984).

A second point of clarification concerns the storage site or reservoir for spermatozoa in the female genital tract of ruminants; this is generally held to be in the folds and crypts of the cervix (Quinlan, Maré and Roux, 1933 ; Dauzier, 1958), with the mucous secretions of that organ playing a favourable rôle (Mattner, 1963, 1966 ; Raynaud, 1973 ; Robinson, 1973). Whilst it is certainly true that the cervix acts as a long-term reservoir for spermatozoa and, next to the site of ejaculation, is the portion of the tract containing the greatest density of sperm cells, it appears not to be the immediate source from which spermatozoa are drawn at the time of ovulation. Rather, this functional reservoir is now considered to be in the caudal portion of the oviduct isthmus (Hunter and Wilmut, 1983), and a local programming of sperm release from this reservoir by means of follicular hormones has been proposed (Hunter, Cook and Poyser, 1983). In other words, a coordination in the meeting of the two gametes would be dictated by the maturity of a Graafian follicle on the verge of ovulation.

The extent of a pre-ovulatory progression of viable spermatozoa in the bovine oviduct remains to be clarified. Because some viable spermatozoa will already have entered the oviducts within 8-10 hours of mating, then an onwards progression of such cells towards the site of fertilisation at the isthmic-ampullary junction might be expected in the further 18-20 hours that will elapse before ovulation. However, this seems not to be the case in another ruminant, the sheep, in which competent cells are largely sequestered in the caudal $1-2 \mathrm{~cm}$ of the oviduct until just before the moment of ovulation (Hunter, Barwise and King, 1982 ; Hunter and Nichol, 1983). The possibility of a similar restriction of viable spermatozoa in heifers has been examined in the present study by means of a surgical approach.

\section{Materials and methods.}

Animals. - Forty-six mature heifers of mixed breeding, predominantly Friesian or Friesian $x$ Hereford crosses, were allocated to the study. The animals were aged approximately $15-18$ months, weighed $350-475 \mathrm{~kg}$, and had not previously been involved in any experimental work. They were housed as two groups in well-ventilated, covered courts at the Animal Breeding Research Organisation, Roslin, and fed a conventional diet of concentrates and hay.

Oestrous regulation and detection. - Animals received two $500 \mu \mathrm{g}$ injections of the prostaglandin analogue cloprostenol (Estrumate; ICl Ltd) administered 11 days apart to reprogramme their oestrous cycles. The day of oestrus induced by the second injection was noted. All animals were then allowed to proceed through a spontaneous cycle and were carefully observed for oestrous behaviour shortly before the anticipated time. Specific details of oestrous detection procedures differed between the two studies to be described. In the first, 
undertaken in June 1983, animals were checked daily between 0600 and 2230 hours. They were under frequent observation for signs of restlessness, mounting and riding behaviour. Only homosexual interactions were possible in the holding courts, but animals considered to be in oestrus were then removed from the court and tested with a mature bull.

In the second study conducted in October 1983, behaviour was monitored every 4 hours throughout the day and night. One of the heifers in the group, not destined for the actual experiment, had been injected with a solution of androgens in oil according to the schedule of Signoret (1975). Checking for oestrus was more precise in this second study since animals deemed to be in prooestrus were tested every 4 hours with a bull until they would stand. Ovarian palpation per rectum was not performed.

Mating and pre-operative routine. - Three Hereford bulls of proven fertility were used throughout the experiment. Heifers newly in oestrus were mated under close supervision by at least two of the bulls, usually within a period of $10 \mathrm{~min}$; a third mating occurred on a few occasions. Mated animals were placed in holding pens adjacent to the principal court, and starved until the moment of operation. The number of animals held together in individual starving pens varied with the progress of the experiment, but frequently it was two or three so there was scope for further homosexual interactions including riding behaviour.

Surgical procedures. - Anaesthesia was induced by means of an intrajugular injection of thiopentone sodium (Intraval; May and Baker Ltd), and endotracheal intubation achieved before positioning the animal on its back on a

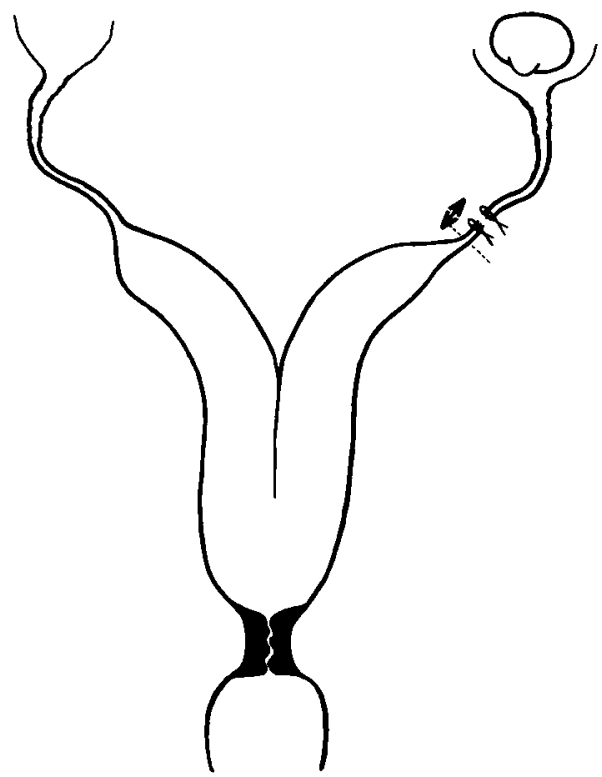

FIG. 1. - Semi-diagrammatic representation of a cow reproductive tract to indicate the position of the double ligatures and point of transection of the oviduct proximal to the utero-tubal junction; this varied from $1.0-3.2 \mathrm{~cm}$. 
hydraulic operating table. Full anaesthesia was maintained by semi-closed circuit administration of halothane (Fluothane ; ICl Ltd), nitrous oxide and oxygen ; the concentration of halothane seldom exceeded $2.0 \%$. Using aseptic procedures, the reproductive tract was located via a mid-ventral laparotomy, the ovaries gently palpated for a mature follicle or recent ovulation, and the horn of the uterus and oviduct on the ovulatory side exposed with a minimum of handling. Double ligatures of No. 2.5 gauge braided silk (Mersilk; Ethicon Ltd) $2 \mathrm{~mm}$ apart were positioned tightly around the wall of the oviduct approximately $1.5-2.0 \mathrm{~cm}$ above the utero-tubal junction in most animals (fig. 1); this distance was modified from $1.0-3.2 \mathrm{~cm}$ in the second part of the study. The oviduct tissue was transected between the ligatures with fine-pointed scissors and damage to the mesosalpinx avoided. After visualizing the ovary without withdrawing it from the abdomen, the tract was restored and the body wall closed in three layers with sutures of No. 5 gauge Dexon (Davis and Geck). Animals recovered in strawbedded pens with access to food and water.

Recovery and examination of eggs. - Animals were killed at the Edinburgh City Abattoir 1-3 days after the operation, usually on the second, and the reproductive tracts returned to the laboratory within one hour. The oviduct adjoining the ovary with a recent ovulation point was dissected free of its

TABLE 1

The distribution of fertilised eggs in the June series of results.

Heifers were double-mated at the onset of oestrus and the oviduct ligated $1.5-3.2 \mathrm{~cm}$ proximal to the utero-tubal junction (UTJ) at various intervals before or after ovulation

\begin{tabular}{|c|c|c|c|c|c|}
\hline $\begin{array}{c}\text { Time } \\
\text { of } \\
\text { Mating }^{a} \\
\text { (GMT) }\end{array}$ & $\begin{array}{l}\text { Interval from } \\
\text { mating to } \\
\text { transection } \\
\mathrm{Hr} \text { min }\end{array}$ & $\begin{array}{c}\text { Condition } \\
\text { of } \\
\text { ovary }\end{array}$ & $\begin{array}{c}\text { Distance of } \\
\text { ligatures } \\
\text { above UTJ } \\
\mathrm{cm}\end{array}$ & $\begin{array}{c}\text { Eggs } \\
\text { fertilised }\end{array}$ & $\begin{array}{l}\text { Number of } \\
\text { accessory } \\
\text { spermatozoab }\end{array}$ \\
\hline 2210 & 1845 & Large follicle & 2.0 & 0 & 0 \\
\hline 2220 & 1924 & - & 1.5 & 1 & 4 \\
\hline 2210 & 1945 & - & 2.0 & 0 & 0 \\
\hline 1700 & 2354 & - & 1.5 & 0 & 0 \\
\hline 1620 & 2357 & - & 2.0 & 1 & 0 \\
\hline 1505 & 2403 & - & 1.8 & 1 & 2 \\
\hline 1615 & 2405 & - & 2.0 & 0 & 0 \\
\hline 1535 & 2410 & - & 2.0 & 0 & 0 \\
\hline 1415 & 2558 & - & 2.0 & 0 & 0 \\
\hline 1415 & 2721 & - & 2.0 & 0 & 0 \\
\hline 0605 & 2807 & - & 2.0 & 0 & 0 \\
\hline 0600 & 2815 & Just ovulated & 2.0 & 1 & 0 \\
\hline 0630 & 2815 & - & 3.2 & 1 & 0 \\
\hline 0625 & 2920 & - & 2.0 & 1 & 20 \\
\hline 0600 & 3217 & - & 1.8 & 1 & 45 \\
\hline 0850 & 3227 & - & 2.0 & 1 & 2 \\
\hline 2200 & 3520 & - & 2.5 & 1 & 3 \\
\hline 2158 & 3536 & - & 2.2 & 1 & 2 \\
\hline
\end{tabular}

a Oestrous behaviour was checked daily from 0600 until 2230 hours.

b Spermatozoa attached to or embedded in the zona pellucida. 
supporting mesentery, and the distance of the ligatures from the utero-tubal junction measured on the straightened (but relaxed) duct. The proximal ligature was removed and the contents of the duct flushed from the ovarian end with warm Eagle's medium (Flow Laboratories) into plastic Petri dishes. The eggs were prepared as whole mounts according to the method of Chang (1952), and checked under the phase-contrast microscope for spermatozoa on or in the zona pellucida. They were then fixed in $25 \%$ acetic alcohol for $24-48$ hours, stained slowly with $1 \%$ orcein in $45 \%$ acetic acid, and once more examined for accessory spermatozoa during swelling and dissolution of the zona. Nuclear structures in the vitellus were also recorded.

Statistical analysis. - Analysis of the mean numbers of eggs fertilised was made with a Chi-squared test.

\section{Results.}

Because the method and frequency of testing for oestrus differed between the June and October series of animals, the results are presented separately for the two groups (tables 1 and 2).

Onset of oestrus. - Twenty-six heifers were mated in the June series : of these, nine (35\%) first showed standing oestrus at 0600 hours, seven $(27 \%)$ at

\section{TABLE 2}

The distribution of fertilised eggs in the October series of results.

Heifers were double-mated at the onset of oestrus and the oviduct ligated 1.0-3.2 cm proximal to the utero-tubal junction (UTJ) at various intervals before or after ovulation

\begin{tabular}{|c|c|c|c|c|c|}
\hline $\begin{array}{c}\text { Time } \\
\text { of } \\
\text { Mating }^{a} \\
\text { (GMT) }\end{array}$ & $\begin{array}{l}\text { Interval from } \\
\text { mating to } \\
\text { transection } \\
\mathrm{Hr} \text { min }\end{array}$ & $\begin{array}{c}\text { Condition } \\
\text { of } \\
\text { ovary }\end{array}$ & $\begin{array}{l}\text { Distance of } \\
\text { ligatures } \\
\text { above UTJ } \\
\mathrm{cm}\end{array}$ & $\begin{array}{c}\text { Eggs } \\
\text { fertilised }\end{array}$ & $\begin{array}{c}\text { Number of } \\
\text { accessory } \\
\text { spermatozoab }^{b}\end{array}$ \\
\hline 1625 & 2333 & Large follicle & 2.0 & 0 & 0 \\
\hline 2008 & 2422 & - & 1.0 & 1 & 0 \\
\hline 0800 & 2432 & - & 2.0 & 0 & 0 \\
\hline 1630 & 2452 & - & 1.2 & 1 & 0 \\
\hline 2035 & 2455 & - & 2.0 & 1 & 11 \\
\hline 2000 & 2456 & - & 1.5 & 1 & 0 \\
\hline 1500 & 2605 & - & 1.5 & 0 & 0 \\
\hline 0425 & 2745 & - & 1.5 & 1 & 1 \\
\hline 1200 & 2759 & - & 2.0 & 0 & 0 \\
\hline 0100 & 3000 & Just ovulated & 2.5 & 1 & 0 \\
\hline 0040 & 3010 & Large follicle & 2.0 & 0 & 0 \\
\hline 0010 & 3021 & Just ovulated & 2.0 & 0 & 0 \\
\hline 0030 & 3040 & - & 2.0 & 1 & 2 \\
\hline 1400 & 3107 & Large follicle & 2.0 & 1 & 30 \\
\hline 0830 & 3212 & Just ovulated & 3.2 & 0 & 0 \\
\hline 0015 & 3300 & - & 3.0 & 0 & 0 \\
\hline 0730 & 3334 & - & 3.0 & 0 & 0 \\
\hline
\end{tabular}

a Oestrous behaviour was checked every 4 hours throughout this series.

b Spermatozoa attached to or embedded in the zona pellucida. 
2200 hours, seven at 1600 hours and three $(11 \%)$ at mid-day. In the October series, six of the 20 mated heifers $(30 \%)$ first showed oestrus at midnight, four (20\%) at 1600 hours, and three each respectively at 0800 hours, mid-day and 2000 hours. Only one animal was newly in oestrus at 0400 hours.

Timing of ovulation. - As noted at laparotomy, the follicle had collapsed in one of the June series of animals 21 hours $6 \mathrm{~min}$ after detection of oestrus ; rupture almost certainly occurred during exposure of the tract. Follicles had not ovulated in 16 animals examined 18 hours 45 min - 28 hours 7 min after the onset of oestrus, whereas recent ovulations were present in nine animals examined 28 hours $15 \mathrm{~min}$ - 35 hours $44 \mathrm{~min}$ after the onset of oestrus. (NB For reasons presented below, eight observations are not included in table 1). In the October series, ovulation had not occurred in nine animals examined 23 hours $33 \mathrm{~min}$ 27 hours $59 \mathrm{~min}$ after the onset of oestrus, nor in two animals examined at 30 hours $10 \mathrm{~min}$ and 31 hours $7 \mathrm{~min}$. Ovulation (ie a collapsed follicle with haemorrhagic stigma) was first observed at $\mathbf{3 0}$ hours, although the 28 and 29 hour intervals were not covered by this series (table 2).

Egg recovery and fertilisation. - Only 18 of the 26 animals (69\%) operated on in the June series yielded eggs at autopsy compared with 17 of the 20 animals $(85 \%)$ in the October series.

Considering the two series of results presented in tables 1 and 2 together, they support the proposal of a pre-ovulatory restriction of spermatozoa to the caudal region of the oviduct with a redistribution of spermatozoa close to the time of ovulation. Thus, eggs were fertilised in only 3 of 14 instances $121 \%$ fertilisation) when ligatures were placed at $2.0 \mathrm{~cm}$ in pre-ovulatory animals between 16 hours $25 \mathrm{~min}$ and 31 hours $7 \mathrm{~min}$ after mating. In contrast and excluding the results of $3.0-3.2 \mathrm{~cm}$ ligatures, 8 of 9 eggs (89\%) were fertilised with oviduct transection in post-ovulatory animals 28 hours 15 min - 35 hours 36 min after mating $(P<0.01)$. A further analysis of the summarised data for the 35 animals yielding eggs, based on the time and position of ligatures, is presented in table 3. The trend in ad-ovarian movement of spermatozoa within the oviduct

\section{TABLE 3}

Analysis of the summarised data for the 35 animals yie/ding eggs, based on the time of transection after mating and the location of the ligatures on the oviduct isthmus proximal to the utero-tubal junction.

The figures indicate the proportion of eggs fertilised

Interval from mating to transection $\mathrm{Hr} \min$

\section{$<2 \mathrm{~cm}$}

$1845-2359$

$2400-2759$

28 00-31 59

32 00-35 36
Location of oviduct ligatures

$$
>2 \mathrm{~cm} \text { but }<3 \mathrm{~cm}>3 \mathrm{~cm}
$$


close to the time of ovulation is again clear, but there are insufficient observations to permit a stronger statement.

Examining the individual results more closely, the following points are apparent. In the June series with ligatures placed on the oviduct isthmus before ovulation, only 3 of 11 eggs were fertilised; in two of these instances, the ligatures were located 1.5 and $1.8 \mathrm{~cm}$, respectively, above the utero-tubal junction rather than at $2.0 \mathrm{~cm}$. By contrast, all 7 eggs were fertilised when ligatures were placed on the oviducts during or after ovulation (table 1). In the October series with pre-ovulatory ligatures placed $2.0 \mathrm{~cm}$ above the utero-tubal junction, 2 of 6 eggs were fertilised ; in the two fertile instances, the operations were performed 24 hours $55 \mathrm{~min}$ and 31 hours $7 \mathrm{~min}$ after mating (table 2). Conversely, in one post-ovulatory animal with a $2.0 \mathrm{~cm}$ ligation 30 hours $21 \mathrm{~min}$ after mating, the egg was not fertilised. When the ligatures were placed at $2.5 \mathrm{~cm}$ exactly 30 hours after mating in a recently ovulated animal, a fertilised egg was recovered, although without any accessory spermatozoa. But with ligatures at $3.0-3.2 \mathrm{~cm}$ in three recently ovulated animals operated on 32 hours $12 \mathrm{~min}-33$ hours $34 \mathrm{~min}$ after mating (table 2), none of the eggs was fertilised nor were spermatozoa associated with the zona pellucida.

Sperm numbers and developmental stages. - The number of accessory spermatozoa attached to or embedded in the zona pellucida of the 18 fertilised eggs was generally low (4 or less), although there were four exceptions (tables 1 and 2). In the June series of 10 fertilised eggs, the range was $0-45$ with a mean of 7.8 sperm per zona. If only those eggs with some attached spermatozoa are considered (7 eggs), the range was 2-45 with a mean of 11.2. In the October series of eight fertilised eggs, the range was $0-30$, with a mean of 5.5 . In the case of the four eggs having some accessory spermatozoa, the range was 1-30 with a mean of 11.0. The largest number of spermatozoa was not associated with the most advanced stage of embryonic development (see tables 1 and 2), nor could it be related simply to the distance of the ligatures beyond the utero-tubal junction. Spermatozoa were not observed on or in the zona pellucida of unfertilised eggs, which were denuded of follicular cells in all instances.

No abnormalities of fertilisation or development could be detected in the 18 penetrated eggs whose stages ranged from pronucleate (with associated portion of the sperm flagellum) to that of 16-cells ; most were 4-8 celled embryos. The rate of development in the transected oviducts was apparently normal, conforming with the reports of Hamilton and Laing (1946) and Thibault (1967). The second metaphase arrangement of chromosomes was visible in all unfertilised eggs, with little dispersal of individual chromosomes in most cases and no fragmentation of the cytoplasm.

\section{Discussion.}

The results are best interpreted in the light of our previous finding that sufficient spermatozoa have entered the oviducts of heifers within 10-12 hours of mating early in oestrus to fertilise most eggs (Hunter and Wilmut, 1983 ; Wilmut 
and Hunter, 1984). These new observations strongly suggest that competent spermatozoa do not progress onwards to the site of fertilisation at the isthmicampullary junction, but rather are sequestered in the caudal $2 \mathrm{~cm}$ of the oviduct isthmus for most of the pre-ovulatory interval. Ovulation is reported to occur some 29-30 \pm 6 hours after the onset of oestrus (Swanson and Hafs, 1971 ; Christenson, Echternkamp and Laster, 1975), or 28 hours after the onset of oestrus in mated animals (Marion et al., 1951), figures that were closely endorsed in the present study. Thus, spermatozoa that have entered the oviducts within 10 12 hours of mating early in oestrus in sufficient numbers to fertilise the egg appear to be largely restricted to the caudal isthmus for a further 18-20 hours. This judgement is based on the appropriate placement of ligatures and the subsequent recovery of fertilised eggs, so the timing is descriptive of viable spermatozoa. It does not take account of cells that may have arrived sooner at the isthmic-ampullary junction and which failed to retain fertilising ability until the time of ovulation, nor does it preclude a possible harmful effect of the transection procedure on the oviductal milieu. Nonetheless, the number of accessory spermatozoa on the zona pellucida of fertilised eggs suggests that the ad-ovarian movement of competent spermatozoa was the principal limitation in the hours before ovulation.

Specific reference must of course be made to the exceptions in the present study. The three fertilised eggs obtained in the June series after pre-ovulatory ligation may in part be attributable to ligation at 1.5 and $1.8 \mathrm{~cm}$ rather than 2.0 $\mathrm{cm}$, and to a less accurate detection of the onset of oestrus. One consequence of the nestrous detection régime used in June was that the timing of operations could in fact have been four or more hours closer to ovulation than recorded and therefore already at the peri- rather than pre-ovulatory stage (see table 1). Fertilisation in the October series with ligatures 24 hours 22 min, 24 hours 52 min and 24 hours 56 min after mating may again have been primarily a result of transection at $1.0,1.2$ and $1.5 \mathrm{~cm}$, respectively, above the utero-tubal junction, whilst the animal operated on at 27 hours 45 min was probably on the verge of ovulation. Even so, it does appear from the two sets of results that the preovulatory restriction of competent spermatozoa to the caudal isthmus of heifers is less precise than in parous sheep (see Hunter and Nichol, 1983). If true, this may reflect minor differences in oviduct morphology and a greater variability in ovulation time. In addition, the methodology in the present experiments of preoperative starving and intravenous injection of barbiturates was not used in the sheep study and may have contributed to the apparent differences, as may the greater traction required to exteriorize the reproductive tissues. Ovarian regulation of oviduct function by a local transfer of high concentrations of follicular hormones (Hunter et al., 1983), if important in ruminants, is unlikely to differ significantly in chronology between sheep and cattle since patterns of follicular steroid synthesis are comparable (Dieleman et al., 1983).

If it is accepted that there is a pre-ovulatory sequestering of spermatozoa in the caudal isthmus of animals mated early in oestrus followed by a progressive peri- and post-ovulatory displacement of viable cells towards the site of fertilisation, as suggested by the results of the $3.0 \mathrm{~cm}$ ligatures, then 
consideration needs to be given to the mechanisms and strategy underlying these phenomena. The lumen of the ruminant isthmus is extremely tightly constricted in the pre-ovulatory interval as inferred by the ad-ovarian direction of flow of oviduct fluids (Bellve and McDonald, 1968), and passage of spermatozoa would be impeded on physical grounds alone. However, a reduced temperature and oxygen tension in the lower isthmus may also act to reduce sperm motility. The latter is depressed in the lumen of the rabbit oviduct before ovulation (Overstreet and Cooper, 1975 ; Cooper, Overstreet and Katz, 1979), and the temperature of the rabbit isthmus at this time is significantly lower than that of the ampulla, a situation that alters abruptly at ovulation or after ovariectomy (David, Vilensky and Nathan, 1972). These physiological changes in the oviducts are under the influence of ovarian hormones, which also act to modify the pattern of oviduct contractions via the population of available $\alpha$-and $\beta$-adrenergic receptors in the myosalpinx (Black, 1974 ; Harper et al., 1976 ; Hunter, 1977). As to the strategy of sperm storage in the lower oviduct, the principal aim may be to locate a population of viable cells in a pre-capacitated state beyond the reaches of polymorphonuclear leucocytes in the uterine lumen. Capacitated spermatozoa are short-lived and fragile cells (reviewed by Bedford, 1970 ; Chang and Hunter, 1975; Yanagimachi, 1981), and there would be little advantage in achieving capacitation 18-20 hours or more before release of the egg. Overall, therefore, the caudal isthmus of the oviduct may represent a specialised storage site for spermatozoa in the pre-ovulatory interval, possibly with a unique fluid environment that maintains sperm cells in a relatively quiescent state. Indeed, there may be quite close parallels in this regard between the caudal portion of the oviduct and that of the epididymal duct (Hunter and Nichol, 1983).

The topic of very rapid transport of bull spermatozoa into the oviducts within minutes of mating as distinct from artificial insemination has been discussed at length (Dauzier, 1958 ; VanDemark, 1958 ; Thibault, 1973 ; Thibault et al., 1973 ; Hunter, 1980 ; Hunter and Wilmut, 1983 ; Wilmut and Hunter, 1984). Our own conclusion is that if such a rapid phase of transport is indeed a consistent feature of mating at the onset of oestrus, then such spermatozoa do not contribute directly to the process of fertilisation. Nonetheless, the observations of VanDemark and Moeller (1951) and VanDemark and Hays (1954) may not be explicable solely on the basis of artefacts arising during experimental manipulation, slaughter or laboratory procedures. Accordingly, the suggestions already advanced by Hunter (1980) and Hunter et al. (1980) that a vanguard of dead or dying sperm cells (1) could release degradation products into the oviduct lumen that interact with the epithelial secretions and the later-arriving spermatozoa and egg to facilitate maturational changes in the gametes, or (2) may function to sensitise the peritoneal phagocytosis system for the subsequent arrival of greater numbers of motile spermatozoa - require further consideration. So also does the proposal of Overstreet (1983) that rapidly transported cells may be local messengers acting to co-ordinate movement of the reproductive tract. Conversely, Hunter and Nichol (1983) have pointed out that there may be marked differences in the rapidity of sperm transport between induced ovulators such as rabbits which soon become refractory to the male after coitus and spontaneous 
ovulators such as cows and sheep in which oestrus lasts for many hours and where repeated mating is therefore possible. Rapid transport after second and subsequent matings in ruminants would be expected to displace competent spermatozoa from the caudal isthmus, especially if smooth muscle contraction is the principal effector of such rapid cell transport. We have no evidence that this occurs (Hunter and Nichol, 1983).

On a practical note, thoughts should now be focussed on the location of the functional sperm reservoir since this could have a bearing on procedures of artificial insemination. Because the incidence of fertilisation in a population of cows seldom exceeds $80-90 \%$ after a single breeding, adequate reserves of viable spermatozoa may not have been established in the oviduct of some animals, even though using semen from proven bulls. Hence, it is worth reconsidering the site of semen deposition during artificial insemination and especially whether introduction of the sperm suspension directly into the horn of the uterus adjoining the ovary with the pre-ovulatory follicle might not be beneficial. Arguments for and against a more precise use of this procedure have been discussed in a recent review (Hunter, 1984). If the overall incidence of fertilisation could be raised by 3 $4 \%$, a small but nationally significant increase in the calving index should be obtained.

Reçu en février 1984.

Accepté en mai 1984.

Acknowledgements. - This study was supported in part by a grant from the Agricultural Research Council to RHFH. Technical assistance was provided by Cameron Manson, Robert Nichol, Marjorie Thomson, Naomi Wray and Mel Zuydam. Mrs Pat Gallie kindly typed the manuscript.

Résumé. Transport des spermatozö̈des chez la vache : redistribution des cellules viables dans l'oviducte au moment de l'ovulation.

Chez des génisses saillies au début de l'œstrus, la migration des spermatozoïdes dans l'oviducte a été étudiée en fonction du temps écoulé depuis l'ovulation. Les techniques utilisées comportent la ligature et la section des oviductes, ainsi que la récupération des œufs. L'ovulation se produit 28 à $31 \mathrm{~h}$ après le commencement de l'œestrus. Les spermatozoïdes aptes à la fécondation sont confinés avant l'ovulation, pendant 18 à $20 \mathrm{~h}$ ou plus, dans la région caudale de l'isthme, avant d'atteindre la jonction entre l'isthme et l'ampoule, lieu de la fertilisation. $20 \%$ des ceufs seulement sont fécondés lorsque l'oviducte est sectionné à $2 \mathrm{~cm}$ de la jonction utéro-tubaire $16 \mathrm{~h}$ ou plus après l'accouplement, tandis que la proportion d'œufs fécondés atteint $88 \%$ lorsque la même opération est réalisée 28 à $36 \mathrm{~h}$ après la saillie. Il semble qu'une redistribution des spermatozoïdes ait lieu au moment de la libération des ceufs. La portion distale de l'oviducte peut donc être considérée comme un réservoir fonctionnel d'où proviendront les spermatozoïdes viables au moment de l'ovulation. Ce phénomène rappelle le stockage des spermatozoïdes dans le canal épididymaire. L'efficacité des techniques d'insémination chez les bovins a été examinée à la lumière des résultats expérimentaux.

\section{Références}

BEDFORD J. M., 1970. Sperm capacitation and fertilisation in mammals. Biol. Reprod., 2, Suppl. 2, 128-158.

BELLVE A. R., McDONALD M. F., 1968. Directional flow of Fallopian tube secretion in the Romney ewe. J. Reprod. Fert., 15, 357-364. 
BLACK D. L., 1974. Neural control of oviduct musculature, 65-118. In A. D. JOHNSON, C. W. FOLEY. The oviduct and its functions, Acad. Press, New York.

CHANG M. C., 1952. Fertilisability of rabbit ova and the effects of temperature in vitro on their subsequent fertilisation and activation in vivo. J. exp. Zool., 121, 351-381.

CHANG M. C., HUNTER R. H. F., 1975. Capacitation of mammalian sperm : biological and experimental aspects. In D. W. HAMILTON, R. O. GREEP, Handbook of physiology, Endocrinology V, Ch. 16, 339-351. Amer. Physiol. Soc., Washington, D. C.

CHRISTENSON R. K., ECHTERNKAMP S. E., LASTER D. B., 1975. Oestrus, LH, ovulation and fertility in beef heifers. J. Reprod. Fert., 43, 543-546.

COOPER G. W., OVERSTREET J. W., KATZ D. F., 1979. The motility of rabbit spermatozoa recovered from the female reproductive tract. Gamete Res., 2, 35-42.

DAUZIER L., 1958. Physiologie du déplacement des spermatozoïdes dans les voies génitales femelles chez la brebis et la vache. Ann. Zootech., 7, 281-301.

DAVID A., VILENSKY A., NATHAN H., 1972. Temperature changes in the different parts of the rabbit's oviduct. Int. J. Gynaec. Obstet., 10, 52-56.

DIELEMAN S. J., BEVERS M. M., POORTMAN J., VAN TOL H. T. M., 1983. Steroid and pituitary hormone concentrations in the fluid of preovulatory bovine follicles relative to the peak of LH in the peripheral blood. J. Reprod. Fert., 69, 641-649.

HAMILTON W. J., LAING J. A., 1946. Development of the egg of the cow up to the stage of blastocyst formation. J. Anat., 80, 194-204.

HARPER M. J. K., PAUERSTEIN C. J., ADAMS C. E., COUTINHO E. M., CROXATTO H. B., PATON D. M., 1976. Ovum transport and fertility regulation. Proc. W. H. O., 1975, San Antonio. Conf., Scriptor, Copenhagen.

HUNTER R. H. F., 1977. Function and malfunction of the Fallopian tubes in relation to gametes, embryos and hormones. Europ. J. Obstet. Gynec. Reprod. Biol., 7, 267-283.

HUNTER R. H. F., 1980. Transport and storage of spermatozoa in the female tract. Proc. 9th int. Congr. anim. Reprod. artif. Insem., Madrid, 2, 227-233.

HUNTER R. H. F., 1984. Towards $100 \%$ fertilisation in inseminated cows, with particular reference to the site of sperm storage. Anim. Breed. Abstr. 52, 1-5.

HUNTER R. H. F., BARWISE L., KING R., 1982. Sperm transport, storage and release in the sheep oviduct in relation to the time of ovulation. Brit. vet. J., 138, 225-232.

HUNTER R. H. F., COOK B., POYSER N. L., 1983. Regulation of oviduct function in pigs by local transfer of ovarian steroids and prostaglandins: a mechanism to influence sperm transport. Europ. J. Obstet. Gynec. Reprod. Biol., 14, 225-232.

HUNTER R. H. F., NICHOL R., 1983. Transport of spermatozoa in the sheep oviduct : preovulatory sequestering of cells in the caudal isthmus. J. exp. Zool., 228, 121-128.

HUNTER R. H. F., NICHOL R., CRABTREE S. M., 1980. Transport of spermatozoa in the ewe : timing of the establishment of a functional population in the oviduct. Reprod. Nutr. Dévelop., 20, 1869-1875.

HUNTER R. H. F., WILMUT I., 1983. The rate of functional sperm transport into the oviducts of mated cows. Anim. Reprod. Sci., 5, 167-173.

MARION G. B., SMITH V. R., WILEY T. E., BARRETT G. R., 1951. The effect of sterile copulation on time of ovulation in dairy heifers. J. Dairy Sci., 33, 885-889.

MATTNER P. E., 1963. Spermatozoa in the genital tract of the ewe. 11. Distribution after coitus. Aust. J. biol. Sci., 16, 688-694.

MATTNER P. E., 1966. Formation and retention of the spermatozoan reservoir in the cervix of the ruminant. Nature, Lond., 212, 1479-1480.

OVERSTREET J. W., 1983. Transport of gametes in the reproductive tract of the female mammal. Chapter 11, In J. F. HARTMANN, Mechanism and control of animal fertilisation. Acad. Press, New York.

OVERSTREET J. W., COOPER G. W., 1975. Reduced sperm motility in the isthmus of the rabbit oviduct. Nature, Lond., 258, 718-719.

QUINLAN J., MARE G. S., ROUX L. L., 1933. A study of the duration of motility of spermatozoa in the different divisions of the reproductive tract of the Merino ewe. Onderstepoort $J$. vet. Sci. anim. Indust., 1, 135-145.

RAYNAUD F., 1973. Physiologie du col de l'utérus de la brebis. Effet d'un progestagène de synthèse : I'acétate de fluorogestone. Ann. Biol. anim. Biochim. Biophys., 13, 335-346. 
ROBINSON T. J., 1973. Factors involved in the failure of sperm transport and survival in the female reproductive tract. J. Reprod. Fert., Suppl. 18, 103-109.

SIGNORET J. P., 1975. Nouvelle méthode de détection de l'œestrus chez les bovins. Ann. Zootech., 24, 125-127.

SWANSON L. V., HAFS H. D. 1971. LH and prolactin in blood serum from estrus to ovulation in Holstein heifers. J. anim. Sci., 33, 1038-1041.

THIBAULT C., 1967. Analyse comparée de la fécondation et de ses anomalies chez la brebis, la vache et la lapine. Ann. Biol. anim. Biochim. Biophys., 7, 5-23.

THIBAULT C., 1973. Sperm transport and storage in vertebrates. J. Reprod. Fert., Suppl. 18, 3953.

THIBAULT C., GÉRARD M., HEYMAN Y., 1973. Transport et survie des spermatozoïdes chez la vache, 343-356. In E. S. E. HAFEZ, C. THIBAULT. Sperm transport, survival and fertilising ability, INSERM, Paris.

VANDEMARK N. L., 1958. Spermatozoa in the female genita! tract. Int. J. Fert., 3, 220-230.

VANDEMARK N. L., HAYS R. L., 1954. Rapid sperm transport in the cow. Fert. Steril., 5, 131 137.

VANDEMARK N. L., MOELLER A. N., 1951. Speed of spermatozoan transport in reproductive tract of estrous cow. Amer. J. Physiol., 165, 674-679.

WILMUT I., HUNTER R. H. F., 1984. Sperm transport into the oviducts of heifers mated early in oestrus. Reprod. Nutr. Dévelop., 24, 461-468.

YANAGIMACHI R., 1981. Mechanisms of fertilisation in mammals. Chapter 5. In L. MASTROIANNI Jr., J. D. BIGGERS. Fertilisation and embryonic development. Plenum Press, New York. 